\title{
THE ROLE OF REWARD-BASED CROWDFUNDING IN FARM FINANCING: WHAT CHARACTERISES SUCCESSFUL CAMPAIGN?
}

\author{
Isidora Ljumovićl, Aida Hanić2, Vlado Kovačević \\ *Corresponding author E-mail: isidora.ljumovic@ien.bg.ac.rs
}

A R T I C L E I N F O
Original Article
Received: 11 June 2021
Accepted: 23 August 2021
doi:10.5937/ekoPolj2103773L
UDC
061.27:338.434]:342.849.2

Keywords:

crowdfunding, agri-business, success factors, farm financing

JEL: Q14, G23, Q13

\begin{abstract}
A B S T R A C T
The purpose of this paper is to provide insight into the role of reward-based crowdfunding in farm financing, with a focus on its likelihood of success. The study uses a sample of 1,566 projects from the Kickstarter platform between 2014 and 2020. We added the level of urbanisation and relative importance of agriculture in the country's economy to the basic elements to assess the importance of the crowdfunding.
\end{abstract}

We run a logistic regression model to investigate factors that motivate investment decisions. We discovered a statistically significant negative correlation between the self-set campaign goal and project success, as well as a small positive impact of number of backers and a positive impact of the importance of agriculture in the country's economy on crowdfunding success. In an era of rapid innovation and the rise of social networks, this paper contributes to the current literature on the agri-food industry's reword-based crowdfunding approach.

(C) 2021 EA. All rights reserved.

\section{Introduction}

As an industry that impacts and influences other economic sectors, agri-business becomes part of a more extensive socio-economic system that creates a universal solution for food availability and quality. Agri-business value chain consists of different subjects from primary agricultural production to the processing and distribution of food products (Njegomir et al., 2017). As those agri-systems have become more integrated, and complex (Zakić et al., 2014), access to finance became increasingly important to

1 Isidora Ljumović, Senior Research Associate, Institute of Economic Sciences, Zmaj Jovina 12, Belgrade, Serbia, Phone: +381 63462 486, E-mail: isidora.ljumovic@ien.bg.ac.rs, ORCID ID (https://orcid.org/0000-0002-8603-9672)

2 Aida Hanić, Research Assistant, Institute of Economic Sciences, Zmaj Jovina 12, Belgrade, Serbia, Phone: +381 60350 2190, E-mail: aida.hanic@ien.bg.ac.rs, ORCID ID (https:// orcid.org/0000-0003-4378-7002)

3 Vlado Kovačević, Senior Research Associate, Institute of Agricultural Economics, Volgina 15 Street, 11000 Belgrade, Serbia, Phone: +381 635544 14, E-mail: vlado_k@iep.bg.ac. rs, ORCID ID (https://orcid.org/0000-0002-2902-6496) 
ensure investment in production, land quality, stable cash flows, improved market access and risk management. The development of higher production outputs and financial outcomes is hampered by a persistent lack of capital in the agricultural production phase (before harvest). (Popović et al., 2018; Kovačević et al., 2018). Because agriculture is characterised by a certain level of unpredictability, financial institutions are hesitant to take production risks associated with natural disasters and other agri-business concerns (IISD, 2015).

Mollick (2014) defines crowdfunding as "the efforts by entrepreneurial individuals and groups - cultural, social, and for-profit - to fund their ventures by drawing on relatively small contributions from a relatively large number of individuals using the internet, without standard financial intermediaries".

According to Pronti and Pagliarino (2018), open innovations (OI) is a concept that can boost the agri-business. Cillo et al. (2018) consider OI as the new paradigm that can "collect ideas from an external environment capable of triggering innovation processes, which can then increase businesses competitiveness". A recent example of improvement of productivity and sustainability in the agri-business is application of crowdfunding by OI combined with "collective intelligence” (O’Reilly, 2007)

The basic elements of every crowdfunding campaign are a project creator, the backers or investors in the idea, the crowdfunding platform, the campaign itself, and the crowdfunding outcomes - succeed or failed (Petruzzelli et al., 2019). The project initiator - someone seeking funds, the investors - a group of people offering to finance, and the platform as an intermediary between the project initiator and the project financier are the basic elements of crowdfunding in practise (Kuti, 2014; Renwick and Mossialos, 2017).

Moritz and Block (2016) point out that crowdfunding refers to raising financial sources from the capital providers or the "crowd" which has created a new paradigm in terms of overcoming bureaucratic obstacles and creating new industries (Fink, 2012). In that aspect, the aim of this paper is to provide insight into the role of farm rewardbased crowdfunding, as agri-food crowdfunding can connect agricultural producers and users and deliver products directly to the consumers, particulary in the urban area (Li et al., 2020; Yu and Rehman Khan, 2021). Also, it can create trust among parties involved in agri-business crowdfunding for agricultural products do not have certainty in production. Shifting from the challenging bank financing to the funding from a considerable number of investors in small percentages, which crowdfunding enables, can be more convenient. In that aspect, we focus on the likelihood of success of this type of financing.

\section{Literature review}

The extensive usage of crowdfunding has been attributed to the commercialisation of the Internet caused by the decreased online search costs, reduced risk exposure and low communication costs, (Agrawal et al., 2014). As pointed by Martinez-Climent et al. 
(2018), it is "a materialisation of the evolution of entrepreneurial finance". In contrast to traditional finance, crowdsourcing allows businesses to raise financing directly from ordinary investors, bypassing conventional financial institutions, business angels, and venture capitalists. Although it is not the sole method to gather funds using the Internet, crowdfunding became an "umbrella" term for other online funding methods, making it one of the most accessible and successful financial vehicles.

Various agri-business aspects have been highlighted in academic literature. Cillo et al. (2018) emphasised the importance of knowledge management capabilities in agribusiness crowdfunding in terms to "collect, systematise, categorise and filter the information they receive from external sources" which means that crowdfunding in the agri-business can help producers be more creative and have an innovative response towards competition (Franceschelli et al., 2018), but also expands the possibilities for making farming smarter (Xiong et al., 2020; Miletić et al., 2020; Živković et al., 2019; Tošović - Stevanović et al., 2020).

In practice, it is a compelling way to finance projects (Hommerova, 2020) that provides value $\square$ added involvement (Macht and Weatherston, 2014) and include marketing benefits beyond the collected funds (Belleflamme et al., 2014; Mollick and Kuppuswamy, 2014). Crowdfunding involves highly educated individuals (Bernardino and Freitas Santos, 2020) and gives the possibility to gain necessary funds in projects early stage. Many online crowdfunding platforms serve as intermediaries between start-ups and investors. Official statistic from Kickstarter webpage shows that since it has been launched in April 2009 up to the mid-May 2021, 20 million people invested in projects, $\$ 5.8$ billion has been pledged, and 201,475 projects have been successfully funded. According to the report "Crowdfunding Market - Growth, Trends, and Forecasts (2020-2025)", it is expected that the crowdfunding market will grow at a compound annual growth rate (CAGR) of over 16\% during the period 2020-2025.

As previously noted, agricultural financing options are limited. Crowdfunding, on the other hand, offers a lot of potential for overcoming these barriers and triggering financing through agribusiness innovation processes. Also, it can bring the possibility of creating trustworthy in food supply chains (Xiong et al., 2020) and raise the importance of food sustainability (Yu and Rehman Khan, 2021). Crowdfunding can be divided into different forms: reward-based, donation-based, lending-based, and equity-based (Stanko and Henard, 2016; Vismara, 2019). The main difference is based on a goal that wants to be achieved (Mollick, 2014). According to Lehner (2013), donation-based crowdfunding is similar to social entrepreneurship, whereas the other three can be classified as traditional venture capital (Mollick, 2014). Li and Du (2020) note that agrifood crowdfunding can be considered as a form of reward-based finance. De Larrea et al. (2019) point out the additional factors of the success in the case of reward-based crowdfunding are: emphasising the community benefits, updating the crowdfunded project, and actively responding to project funders' comments. 
This is essential in the context of agri-crowdfunding because reward-based crowdfunding is a two-sided market (Tomczak and Brem 2013), with funders acting as early customers (Mollick, 2014) who evaluate the products and receive a reward for backing a project. The type of reward might range from simple thank-you letters to unique services, as well as certain material compensations. (Gerber et al., 2012; Zhao and Ryu, 2020). It's worth noting that the number of incentives can have an impact on the success rate (Lin et al., 2016).

Li et al. (2020) observed the issue of prospect theory, also called a theory of choice, including a behavioural model where people choose between alternatives that involve risk and uncertainty. Based on this theory, Li et al. (2020) note that backers in the agrifood campaigns do not make rational decisions. This could be explained by the fact that the agri-business is highly seasonal, and several problems could occur, such as product storage and eventually access to fresh food. In that aspect, the authors note that the "crowd" in the agri-business campaigns is more similar to online shoppers. Product, person, service, and image value, together with monetary cost, drives a rapid achievement of a funding target in agri-business crowdfunding campaigns ( $\mathrm{Li}$ and Du, 2020).

We are focusing on an under-researched area of farming by exposing the factors impacting the success of crowdfunding campaigns, keeping in mind the various research focus of crowdfunding discovered thus far. In this paper, our attention is on analysing basic factors already identified in the academic literature, as well novel, particular ones discovered in our research.

\section{Materials and methods}

This study uses a reward-based crowdfunding campaigns dataset from Kickstarter, the most popular and one of the oldest crowdfunding platforms. Kickstarter is an "all or nothing" model of platforms, where the entrepreneur keeps nothing unless the goal is achieved, opposite to the "keep it all" model where the creator keeps any funds raised regardless of whether the goal is achieved (Cumming et al., 2019). We used a scraper robot that crawls projects from the Kickstarter webpage (kickstarter.com, last entry 5 February 2021) and collects data for each campaign. Thus, we have gathered over 200.000 campaigns in all categories from Kickstarter, covering the period from 2014 to 2020 .

Because farming-related crowdfunding campaigns are of particular interest to us, we limited the sample to Kickstarter's Food category. All other categories (art, comics, dance, design, fashion, film and video, games, music, photography, publishing, technology, and theatre) were excluded from the research. The category Food has numerous subcategories not related to farming, such as drinks, restaurants, cookbooks, or processed Food. We limited our research only to subcategories Farms and Community Gardens, all other subcategories being excluded since we wanted to analyse factors affecting only campaigns related to the farming. This way, we have attained an adequate sample for the analysis. Before performing the analysis, we further applied several 
filters. We excluded all active, cancelled, and suspended projects since we could not know their outcome. Active projects were ongoing at the moment of our analysis; cancelled projects were terminated by the creator before the end of the duration, while suspended were ended for violating some of the platform rules.

In line with existing literature (Mollick, 2014; Calic and Mosakowski, 2016; Cumming et al., 2017; Liang et al., 2020 and Ni et al., 2021), we have reduced the initial sample and left out campaigns of too small and too big values. On the contrary to the contemporary authors who most often use thresholds from $\$ 1.000$ to $\$ 1.000 .000$, we excluded project below $\$ 500$ and above the 99-percentile of the distribution, which was in the case of our sample value of over $\$ 500,000$. We have lowered the threshold value because projects in the subcategories Farms and Community Garden have, on average, lower campaign goal than their counterparties from other categories. Projects with extreme values may have different characteristics from most projects (Liang et al., 2020). Campaigns with a small goal frequently lack real aim and, as a result, lack the project's necessary complexity. They may target family and friends (Cumming et al., 2017) or usually want free advertisement (Gerber et al., 2012; Mollick, 2014). Projects with extremely high values set as a goal are usually not suited for crowdfunding financing and should focus on more established or traditional sources such as venture capitalist, angel investors and financial institutions.

Thus, we have finalized our sample with 1.567 campaigns on Kickstarter in the period 2014-2020 in the subcategories Farms and Community Garden. Typical projects include the development of Aquaponic Farm, building organic farms, offering Garden Boxes with a set of fruit or vegetables, developing fertilizers or breeding healthy microorganisms for fertilising, locally grown products such as perishable fresh foods such as vegetables, aquatic products, eggs, and meat.

Using a scraper robot for crawling projects from the Kickstarter webpage, we have received information about major attributes of every single campaign: campaign ID, an ID of the creator, a short, concise, effective introduction and description of the campaign, so-called blurb, goal of the campaign (\$), blurb length, currency, time of launching the campaign, duration of the campaign, number of backers, the status of the campaign (active, succeeded, suspended, cancelled, or failed), pledged funds (\$), category and subcategory, city and country of the creator. We added features linked to urbanisation to this data set, defining campaigns as being started in rural areas, towns, or cities, to see if there was a link between the effectiveness of farming efforts and the number of people living in the community. We used the Degree of Urbanization defined by the UN Statistical Commission and created a variable taking the value 2 if the campaign was initiated in settlement with more than 50.000 people, marking it as a city. Towns and semi-dense areas are coded as 1 with a population of at least 5,000 inhabitants (up to 50.000), while rural areas were marked with zero, with a population below 5.000. We did not use density grid cells in our classification. 
To capture the relative importance of agriculture in the country's economy regarding generating national income, we used data from the World Bank (World Development Indicators) for the indicator "agriculture, value added (\% of GDP)" that includes forestry, hunting, and fishing, as well as cultivation of crops and livestock production.

In line with similar studies on crowdfunding performance, we used crowdfunding success as a dependent variable. The dummy variable success is a dichotomous variable, taking the value 1 if the campaign goal was achieved, i.e., if the campaign was successful, or zero elsewise, meaning that the campaign is treated as failed. We derived multiple variables of the project characteristic from the Kickstarter: project goal, duration of the funding period, number of backers, complexity, extended them with data on urbanisation and the level of agriculture to GDP, and tested them against the success of the campaign.

As in several previous research (Mitra and Gilbert, 2014; Beier and Wagner, 2015; Calic and Mosakowski, 2016; Butticè et al., 2017; Colombo et al., 2015; de Larrea et al., 2019; Butticè, et al., 2019; Ni et al., 2021), the project goal is identified as one of the major factors of success. Kickstarter is an open platform to funders worldwide, without the upper limit in setting the goal - creators on their initiative asset the amount of funds they want to attract during the campaign. Similar projects can have different funding goals; however, it is advisable to be realistic when setting the target values. We expect that higher target values will be less likely to reach. Therefore, higher target values decrease the chance of project success. Due to the high skewness of the distribution data related to the target value, we used the logarithm of the target capital (log_target).

Kickstarter projects can last from 1 to 60 days. The duration of the project campaign is the period in which the campaign is active. According to Mollick (2014); Hörisch (2015); Cumming et al. (2017); Butticè et al. (2019); Liang et al. (2020); Ni et al. (2021), it can be expected for shorter campaign duration to have the higher chances for success. It is important to achieve crowdfunding targets quickly, in shortest duration possible, since it has positive effects on raising sufficient funds and meeting the specific and personalised needs of the consumers and deliver it on time (Li and Du, 2020).

Backers are investors who pledge money in the project idea to join creators in completing the project through the creative process. They are crucial as they create word of mouth awareness (Stanko and Henard, 2017). As in Cumming et al., 2017; Stanko and Henard, 2017; Wang et al., 2017; Vismara, 2019; Hörisch and Tenner (2020), we included the number_of_backers into our model. We can expect that the number of backers attracted to the campaign has a positive relationship with the success.

There are several approaches for measuring the complexity of a project. In this paper, we followed Mitra and Gilbert (2014) and Wang et al. (2017) and used the blurb_lenght as the number of letters counted in the project short description. An analysis of the number of words and phrases in the project blurb suggested that more persuasive phrases can attract more project backers (Mitra and Gilbert, 2014), where an accurate description of a project through the blurb would likely have an impact on attracting more backers. 
We derived two additional variables: level of urbanisation and the importance of agriculture relative to the country's economy. As in rural areas, agriculture represents the predominant land use and a major driving force of rural areas livelihood, we assumed that the level of urbanisation can be one of the success factors. Thus, we tested the odds in our model. The importance of the agricultural sector in the country depends on numerous conditions and varies among countries. In this case, we used the relation of agriculture in GDP (agri_to_GDP).

The descriptive statistics of the linked sample used in this research are shown in Table 1. The percentage of successful projects in the subcategories Farms and Community Gardens is $24.3 \%$ which is slightly below the statistic related to the Food category (25.64\% as of May 2021) on the Kickstarter platform. However, if we compare the success of campaigns in the category Food to the success of all campaign that was $38.73 \%$ (data as of May 2021), we can conclude that Kickstarter campaigns related to Food attract less attention. During the considered time window, the average funding goal was $\$ 32,620.8$, while the average amount pledged was more than seven-time smaller and amounted to $\$ 4.177 .32$. In both variables, the standard deviation is high, pointing to the high dispersion in the sample. Farming campaigns are characterised by average duration of 35.5 days and the number of backers slightly higher than 38 . More than half of the creators of the campaigns are from rural areas $(52.2 \%)$, followed by town $(29.5 \%)$ and city residents $(18.3 \%)$. The vast majority of the campaigns in the sample began between 2014 and 2015.

Table 1. Descriptive statistic of sample

\begin{tabular}{|c|c|c|c|c|}
\hline Characteristic & \multicolumn{4}{|l|}{ Sample } \\
\hline No. of projects & \multicolumn{4}{|l|}{1566} \\
\hline \multirow[t]{2}{*}{ Successful projects (\%) } & \multicolumn{4}{|l|}{$380(24.3)$} \\
\hline & Minimum & Maximum & Mean & Std. Deviation \\
\hline Goal for collecting & 500 & 500,000 & $32,620.8$ & $63,773.38$ \\
\hline Amount pledged & 0 & 155,284 & 4.177 .32 & $11,959.25$ \\
\hline Duration & 5 & 90 & 35.5 & 12.57 \\
\hline Backers & 0 & 1,499 & 38.02 & 95.977 \\
\hline Blurb Length & 8 & 148 & 115.04 & 25.854 \\
\hline Level of urbanisation & \multicolumn{4}{|c|}{ Number of campaigns (\% of campaigns) } \\
\hline City & \multicolumn{4}{|c|}{$286(18.3 \%)$} \\
\hline Town & \multicolumn{4}{|l|}{$462(29.5 \%)$} \\
\hline Rural & \multicolumn{4}{|l|}{$818(52.2 \%)$} \\
\hline Year & \multicolumn{4}{|c|}{ Number of campaigns (\% of campaigns) } \\
\hline 2014 & \multicolumn{4}{|c|}{$358(22.9 \%)$} \\
\hline 2015 & \multicolumn{4}{|l|}{$447(28.5 \%)$} \\
\hline 2016 & \multicolumn{4}{|l|}{$243(15.5 \%)$} \\
\hline 2017 & \multicolumn{4}{|l|}{$181(11.6 \%)$} \\
\hline 2018 & \multicolumn{4}{|l|}{$130(8.3 \%)$} \\
\hline 2019 & \multicolumn{4}{|l|}{$130(8.3 \%)$} \\
\hline 2020 & \multicolumn{4}{|l|}{$77(4.9 \%)$} \\
\hline
\end{tabular}

Source: Authors 


\section{Results}

Since our dependent variable success is a dichotomous variable taking a value of either 1 (succeeded) or 0 (failed) we run a logit estimates as in previous research (Mollick, 2014; Hörisch, 2015; Hörisch, 2018; Butticè et al., 2019; Song et al., 2019; Liang et al., 2020).

$$
P 1\left(Y_{i}=1\right)=\frac{1}{1+e^{-\left(\alpha+\beta_{1} X_{1 i}+\beta_{2} X_{2 i}+\beta_{8} X_{3 i}+\beta_{4} X_{4 i}+\beta_{5} X_{5 i}+\beta_{6} X_{6 i}\right)}},
$$

Where:

$\mathrm{X}_{1=}$ log_target

$\mathrm{X}_{2=}$ campaign_duration

$\mathrm{X}_{3=}$ number_of_backers

$\mathrm{X}_{4=}$ blurb_lenght

$\mathrm{X}_{5=}$ urbanization

$\mathrm{X}_{6=}$ agri_to_GDP

As this research aimed to estimate variable that have the odds to contribute to the farm crowdfunding, we presented the results of our probit estimation in Table 2 . The model is statically significant $(\mathrm{p}<0.01)$ and explains the relevant share of the variation of the dependent variable (Pseudo R2 Nagelkerke R Square 0.795). We found a statistically significant relationship for three out of six chosen variables, including project goal, number of backers and the relative importance of agriculture in the country's economy. As expected, the project goal has a negative, statistically significant regression coefficient (-3.64). We interpret this as each increase in the value of project goal decreases the odds of campaign success. This is the single, most important variable in the model with the highest correlation coefficient and with the greatest impact in the model. To be more specific, setting the project goal has the highest relation to success, where projects with lower funding values set as a goal have a greater chance of reaching the target and being successfully funded. The number of backers is positively related to the campaign's success (0.09), where more investors increase the odds of campaign success. However, small coefficients point out to relatively small influence.

The share of agriculture, forestry, and fishing in GDP has a negative, statistically significant regression coefficient (-0.709), indicating that lower values of this variable show better odds for the success of the campaigns related to farming. In other words, countries with relatively lower importance of agriculture in the country's economy have the greater odds for success of farming-related campaigns. Other variables in the model are not statistically significant.

Duration has a small negative coefficient, indicating that the longer the campaign is, the odds for success are lower. Also, the length of the project description (blurb_lenght) is 
not significant with a small value of the correlation coefficient. The results related to the level of urbanisation show that the odds of successful farming campaigns increase with the higher level of urbanisation. Although not statistically significant, the odds of success are the highest if the campaign is initiated in the city, followed by town. The results are compared to a rural settlement category as a baseline.

Table 2. Binary logistic results

\begin{tabular}{|c|c|}
\hline Model summary & Model 1 \\
\hline Dependent variable & Funding Success \\
\hline Pseudo R ${ }^{2}$ (Nagelkerke R Square) & 0.795 \\
\hline Significance of the model & 0.000 \\
\hline Parametric rating & $-3.643^{* * *}$ \\
\hline log_target & $(0.299)$ \\
\hline number_of_backers & $0.088^{* * *}$ \\
\hline & $(0.006)$ \\
\hline campaign_duration & -0.015 \\
\hline & $(0.009)$ \\
\hline blurb_lenght & -0.004 \\
\hline & $(0,004)$ \\
\hline urbanization $=$ rural & $0^{\mathrm{a}}$ \\
\hline & $/$ \\
\hline urbanization $=$ town & 0.257 \\
\hline & $(0.250)$ \\
\hline urbanization $=$ city & 0.454 \\
\hline & $(0.306)$ \\
\hline agri_to_GDP & $-0.709^{* * *}$ \\
\hline & $(0.364)$ \\
\hline Constant & $10.939^{* * *}$ \\
\hline & 1.176 \\
\hline
\end{tabular}

a. Set to zero because this parameter is redundant.

Standard errors are in parentheses and $* * *$ Significance level: 0.01 .

\section{Discussions}

This research contributes to the existing literature on the empirical analysis of the Kickstarter campaigns, with a focus on crowdfunding farming projects. The academic literature on crowdfunding is extensive, with several research directions available. However, research focused on agri-business are scarce and appeared recently. In this article, we attempted to evaluate characteristics that increase the possibility of meeting self-imposed goals. In line with mainstream research papers on crowdfunding, we found a statistically significant negative correlation between the self-set campaign goal and project success. Even at first glance, this is expected since the higher the amount of funds required to be raised, the lower the chances of success are. Our finding on a sample of farming-related crowdfunding campaign coincides with general research 
related to crowdfunding from Mitra and Gilbert (2014), Beier and Wagner (2015); Calic and Mosakowski (2016); Butticè et al. (2017); Colombo et al. (2015); de Larrea et al. (2019), Butticè, et al. (2019), who all found a strong negative relationship between these variables. The results are also consistent with similar research on agri-food from Li et al. (2020); Ni et al. (2021). Both studies found that the project goal is highly relative in agri-food crowdfunding campaigns.

In line with Cumming et al. (2017); Stanko and Henard (2017); Wang et al. (2018); Vismara (2019); Hörisch and Tenner (2020), we also found that the number of backers has a positive impact on crowdfunding success. The difference between our finding and those of mentioned authors are in the value of the regression coefficient, that is to the level of the importance of the number of backers. While we found a relatively week connection, the other author found number of backers to be a more important predictor of success. We can explain this as follows. The goal amounts in the farming campaigns are relatively smaller compared to all categories of crowdfunding campaigns on Kickstarter, and thus a smaller number of backers can achieve the funding goal. Also, as Li et al. (2020), concluded the backers of agri-food crowdfunding are both investors and consumers.

We could not support findings on the duration or the quality of the project since we did not find consistent and statistically significant results. However, both coefficients are negative and small, going in favour of a negative effect on the funding success. Results for the campaign duration are correlated with Mollick (2014), Thies et al. (2019), Cumming et al. (2017), Butticè et al. (2019), Hong and Ryu (2019); and Chen et al. (2019). We borrowed the explanation from Li et al., 2020 stipulating that campaign duration significantly decreases the chances of success, possibly because longer durations are a sign of a lack of confidence, since most of the agri-food products on crowdfunding platform are perishable fresh foods with strong randomness of output and demand (such as vegetables, aquatic products, eggs, and meat), and the campaign should be completed within the shortest time.

Finally, we complemented the set of fundamental indicators with variables important to farming crowdfunding. Despite our expectations that the campaigns initiated in rural communities will have higher odds of success, the results show the opposite, nevertheless, without statistical significance. Our assumption was that the supporters of the farming campaigns are from the local area, where smaller communities are more connected. On the other hand, crowdfunding is initially created for innovative products and services, thus, the main purpose is to seek resources for innovation-driven agricultural products (Đurđenić, 2017), which are more prevalent in urban areas, while campaign creators in rural communities usually offer somewhat simpler products and services.

Prior research confirmed that if a country finances a particular industry or a specific concept, such as agriculture or sustainability, funding opportunities are greater, and therefore fewer projects seek alternative sources of funding, throughout crowdfunding (Butticè et al., 2019; Ljumović and Hanić, 2021). Following this theory, we can expect 
the campaigns initiated in countries with relatively lower importance of agriculture in the country's economy to have higher odds for success. Our result from the Kickstarter platform go in favour of this claim as the percentage of agriculture, forestry, and fishing to GDP has a negative, statistically significant regression coefficient. We relate the explanation for such results with Butticè et al. (2019), who found that when a country puts environmental issues at the top of its priorities, more financial sources are available, and entrepreneurs have more opportunities other than the use of alternative finance, such as crowdfunding. Countries with the most developed agriculture, such as the Netherlands, have a low share of agriculture in the GDP, considering that their other branches of the economy are even more developed. As a rule, underdeveloped countries have a high level of agriculture's share in GDP. It is likely that the more developed countries are, the crowdfunding instruments have the better chances of success. Ljumović and Hanić (2021), also found evidence that countries with the focus on circular economy have lower odds of the campaigns with the elements of circularity.

This research has limitations that could be addressed in the future period. The study uses data only from one reward-based platform - Kickstarter. Although it is difficult to include other platforms because of the difference in parameters, in the future period sample can be extended to other reward-based platforms. Next, we used several milestones determinants that influence campaign success. However, certainly, there are additional important factors that should be included in the analysis.

\section{Conclusions}

As an open innovation concept that can prevail the lack of financial resources in agricultural entrepreneurship, crowdfunding is a promising financing tool that can overcome the shortcomings of traditional sources of funding. Agri-food crowdfunding is a reward-based concept that allows entrepreneurs and farmers to raise small amounts of money from a group of investors (the crowd) for early-stage ventures. In return, the investors receive a reward. In that aspect, this research aimed to provide insight into the role of reward-based crowdfunding in farm financing, exposing the factors influencing the success of farming-related crowdfunding campaigns. The model used in this research included six variables: goal, duration, number of backers, blurb length, the level of urbanisation and relative importance of agriculture in the country's economy. The first four variables are standard in this type of study, but the last two were added because agriculture is typically associated with rural areas, and we assumed that the level of urbanisation could be one of the success factors, as well as because the importance of agriculture in the overall economy changes as the country develops.

Given the importance of agriculture, we analysed 1,566 projects from the Kickstarter platform for the period 2014-2020. Crowdfunding can be considered a potential option of financing initiatives, despite its lack of popularity in the farming field. To attract more donors, our findings reveal that farmers should pay special attention to creating realistic, as minimal as possible goals. In the agri-food crowdfunding small number of backers can achieve smaller on average funding goals. Additionally, we can expect 
more successful campaigns in countries with relatively lower importance of agriculture in the country's economy. In other words, the odds of farming campaign success increase with lower, realistically project values, the greater number of the backers and in countries where the importance of agriculture in the economy is lower.

\section{Acknowledgements}

This paper is a result of the research financed by the Ministry of Education, Science and Technological Development of the Republic of Serbia.

\section{Conflict of interests}

The authors declare no conflict of interest.

\section{References}

1. Agrawal, A., Catalini, C., \& Goldfarb, A. (2014). Some Simple Economics of Crowdfunding In J. Lerner, and S. Stern (Eds.). Innovation Policy and the Economy, Vol. 14, p. 63-97, Chicago, IL, USA: University of Chicago Press.

2. Beier, M., \& Wagner, K. (2015). Crowdfunding Success: A Perspective from Social Media and E-Commerce. In Proceedings of the $26^{\text {th }}$ International Conference on Information System: Exploring the Information Frontier, Fort Woeth, 634-655.

3. Belleflamme, P., Lambert, T., \& Schwienbacher, A. (2014). Crowdfunding: tapping the right crowd. Journal of business venturing, 29(5), 585-609.

4. Bernardino, S., \& Freitas Santos, J. (2020). Crowdfunding: An Exploratory Study on Knowledge, Benefits and Barriers Perceived by Young Potential Entrepreneurs. Journal of Risk and Financial Management, 13(4), 1-24.

5. Buttice, V., Colombo, M. G., \& Wright, M. (2017). Serial crowdfunding, social capital, and project success. Entrepreneurship Theory and Practice, 41(2), 183-207.

6. Butticè, V., Colombo, M. G., Fumagalli, E., \& Orsenigo, C. (2019). Green oriented crowdfunding campaigns: Their characteristics and diffusion in different institutional settings. Technological Forecasting and Social Change, 141, 85-97.

7. Calic, G., \& Mosakowski, E. (2016). Kicking off social entrepreneurship: How a sustainability orientation influences crowdfunding success. Journal of Management Studies, 53(5), 738-767.

8. Chen, Y., Dai, R., Yao, J., Li, Y. (2019). Donate Time or Money? The Determinants of Donation Intention in Online Crowdfunding. Sustainability, 11, pp. 1-21.

9. Cillo, V., Rialti, R., Bertoldi, B., Ciampi, F. (2018). Knowledge management and open innovation inagri-food crowdfunding. British Food Journal, 121(2), 242 258.

10. Colombo, M.G., Franzoni, C., \& Rossi-Lamastra, C. (2015). Internal Social Capital and the Attraction of Early Contributions in Crowdfunding. Entrepreneurship Theory and Practice, 39 (1), 75-100. 
11. Cumming, D. J., Leboeuf, G., \& Schwienbacher, A. (2017). Crowdfunding cleantech. Energy Economics, 65, 292-303.

12. Cumming, D., Meoli, M., \& Vismara, S. (2019). Investors' choices between cash and voting rights: Evidence from dual-class equity crowdfunding. Research Policy, 48(8), 103740.

13. De Larrea, G. L., Altin, M., \& Singh, D. (2019). Determinants of success of restaurant crowdfunding. International Journal of Hospitality Management, 78, 150-158.

14. Đurđenić, K. (2017). Crowdfunding-Croatian legal perspective and comparison to other sources of financing. Public Sector Economics, 41(2), 259-287.

15. Fink, A. (2012). Protecting the Crowd and Raising Capital Through the JOBS Act. Available at SSRN: https://ssrn.com/abstract=2046051

16. Franceschelli, M.V., Santoro, G., \& Candelo, E. (2018). Business model innovation for sustainability: a food start-up case study. British Food Journal, 120 (10), 2483-2494.

17. Gerber, E. M., Hui, J. S., \& Kuo, P. Y. (2012). Crowdfunding: Why people are motivated to post and fund projects on crowdfunding platforms. In Proceedings of the international workshop on design, influence, and social technologies: techniques, impacts and ethics 2(11), 10.

18. Hommerova, D. (2020). Crowdfunding as a New Model of Nonprofit Funding. In I. Garcia-Rodriguez, E. Romero-Merino (Eds.), Financing Nonprofit Organizations, London: Routledge, chp. 13.

19. Hong, S., \& Ryu, J. (2019). Crowdfunding public projects: Collaborative governance for achieving citizen co-funding of public goods. Government Information Quarterly, 36(1), 45-153.

20. Hörisch, J. (2015). Crowdfunding for environmental ventures: an empirical analysis of the influence of environmental orientation on the success of crowdfunding initiatives. Journal of Cleaner Production, 107, 636-645.

21. Hörisch, J. (2018). 'Think big'or'small is beautiful'? An empirical analysis of characteristics and determinants of success of sustainable crowdfunding projects. International Journal of Entrepreneurial Venturing, 10(1), 111-129.

22. Hörisch, J., \& Tenner, I. (2020). How environmental and social orientations influence the funding success of investment-based crowdfunding: The mediating role of the number of funders and the average funding amount. Technological Forecasting and Social Change, 161, 120311.

23. IISD. (2015). Investment Contracts for Agriculture: Maximizing gains and minimizing risks. World Bank.

24. Kovačević, V., Vasiljević, Z., Zakić, V. (2018). Pre-Harvest Financing in Agriculture. Agroekonomika: časopis Instituta za ekonomiku poljoprivrede $i$ sociologiju sela, 47(80), 23-31. 
25. Kuti, M. (2014). Crowdfunding. Public Finance Quarterly, 59(3), 355-366.

26. Lehner, O. M. (2013). Crowdfunding Social Ventures: A Model and Research Agenda. Venture Capital, 15(4), 289-311.

27. Li, Y., Du, J. (2020). What drives the rapid achievement of a funding target in crowdfunding? Evidence from China. Agricultural Economics-Czech, 66, 269-277.

28. Li, Y., Du, J., \& Fu, W. (2020). Thirty days are enough: what determines the crowd's cash time in agri-food crowdfunding?. China Agricultural Economic Review, 12(3), 553-575.

29. Liang, X., Hu, X., \& Jiang, J. (2020). Research on the Effects of Information Description on Crowdfunding Success within a Sustainable Economy-The Perspective of Information Communication. Sustainability, 12(2), 650.

30. Lin, Y., Lee, W. C., Chang, C. C. H. (2016). Analysis of rewards on reward-based crowdfunding platforms. IEEE/ACM International Conference on Advances in Social Networks Analysis and Mining, Danvers, pp. 501-504.

31. Ljumović, I, \& Hanić, A. (2021). Characteristic of crowdfunding campaigns related to the circular economy projects: Evidence from EU countries. Economic Development - Journal of the institute of economics - Skopje, 24(1), pp. 28-40.

32. Macht, S.A., \& Weatherston, J. (2014). The Benefits of Online Crowdfunding for Fund-Seeking Business Ventures. Special Issue: Firm's Strategy, Organization, and Financial Performance, 23(1-2), 1-14.

33. Martinez-Climent, C., Zorio-Grima, A., \& Ribeiro-Soriano, D. (2018). Financial return crowdfunding: literature review and bibliometric analysis. International Entrepreneurship and Management Journal, 14(3), 527-553.

34. Miletić, A., Belokapić, P., \& Nešić, B. (2020). Specifics of innovation project portfolio management. Oditor - časopis za menadžment, finansije i pravo, 6(2), 91-107. https://doi.org/10.5937/Oditor2002091M

35. Mitra, T., \& Gilbert, E. (2014). The language that gets people to give: Phrases that predict success on Kickstarter. In Proceedings of the 17th ACM conference on Computer supported cooperative work \& social computing, Baltimore, pp. 49-61.

36. Mollick, E. (2014). The dynamics of crowdfunding: An exploratory study. Journal of business venturing, 29(1), 1-16.

37. Mollick, E. R., \& Kuppuswamy, V. (2014). After the Campaign: Outcomes of Crowdfunding. Research Paper No. 2376997, available at SSRN: https://ssrn. com/abstract $=2376997$

38. Moritz, A., \& Block, J.H. (2016). Crowdfunding: A Literature Review and Research Directions. FGF Studies in Small Business and Entrepreneurship, In: Dennis Brüntje \& Oliver Gajda (Eds.). Crowdfunding in Europe, Edition 1, pp. 25-53, Springer.

39. Ni, A. M., Huang, L., \& Xiong, F. (2021). A new perspective of innovation-driven agricultural sustainable development: a case of China. In IOP Conference Series: Earth and Environmental Science, Beijing, 667(1), IOP Publishing. 
40. Njegomir, V., Tepavac, R., \& Ivanišević, N. (2017). Alternative sources of financing entrepreneurial undertakings in agriculture. Economics of Agriculture, 64(1), 295-306.

41. O'Reilly, T. (2007). What is Web 2.0: Design Patterns and Business Models for the next generation of software". Communication \& Strategies, 65, pp. 17-37.

42. Petruzzelli, A. M., Natalicchio, A., Panniello, U., \& Roma, P. (2019). Understanding the crowdfunding phenomenon and its implications for sustainability. Technological Forecasting and Social Change, 141, 138-148.

43. Popović S., Janković I., \& Ž. Stojanović. (2018). The Importance of Bank Credits for Agricultural Financing in Serbia. Economics of Agriculture, 65(1), 65-80.

44. Pronti, A., Pagliarino, E. (2018). Not just for money. Crowdfunding a new tool of Open Innovation to support the Agro-Food sector. Evidences on the Italian market. Journal of Agricultural \& Food Industrial Organization, 17(1), 2-25.

45. Renwick, M., \& Mossialos, E. (2017). Crowdfunding our health: Economic risks and benefits. Social Science \& Medicine, 191, 4-56.

46. ResearchAndMarkets.(2020). Crowdfunding Market - Growth, Trends, and Forecasts (2020-2025). UK

47. Song, Y., Berger, R., Yosipof, A., \& Barnes, B. R. (2019). Mining and investigating the factors influencing crowdfunding success. Technological Forecasting and Social Change, 148, 119723.

48. Stanko, M.A., \& Henard, D.H. (2017). Toward a Better Understanding of Crowdfunding, Openness and the Consequences for Innovation. Research Policy 46(4), 1-45.

49. Thies, F., Huber, A., Bock, C., Benlian, A., \& Kraus, S. (2018). Following the Crowd-Does Crowdfunding Affect Venture Capitalists' Selection of Entrepreneurial Ventures? Small Business Management, 57(4), 1378-1398.

50. Tomczak, A., \& Brem, A. (2013). A conceptualized investment model of crowdfunding. Venture Capital, 15(4), 335-359.

51. Tošović-Stevanović, A., Ćalović, D., Lalić, G., Žuža, M., \& Cvijanović, G. (2020). Comparative analysis of the economic potential of the small and family farms in the Republic of Serbia and Romania. Economics of Agriculture, 67(3), 667-681.

52. Vismara, S. (2019). Sustainability in Equity Crowdfunding. Technological Forecasting and Social Change, 141, 98-106.

53. Wang, W., Zhu, K., Wang, H., \& Wu, Y. C. J. (2017). The impact of sentiment orientations on successful crowdfunding campaigns through text analytics. IET Software, 11(5), 229-238.

54. Xiong, H., Dalhaus, T., Wang, P., \& Huang, J. (2020). Blockchain Technology for Agriculture: Applications and Rationale. Frontiers in Blockchain, 3, article 7. 
55. Yu, Z., \& Rehman Khan, S.A. (2021). Evolutionary game analysis of green agricultural product supply chain financing system: COVID-19 pandemic. International Journal of Logistics Research and Applications, on line article, 1-21,

56. Zakić, N., Vukotić, S., \& Cvijanović, D. (2014). Organisational Models In Agriculture With Special Reference To Small Farmers. Economics of Agriculture, 61 (1), 1-13.

57. Živković, A., Pantić, N., \& Rosić, M. (2019). Fiscal sustainability of the macroeconomic system of European Union members. Oditor - časopis za menadžment, finansije $i$ pravo, 5(2), 32-41. https://doi.org/10.5937/ Oditor1902033Z

58. Zhao, L., Ryu, S. (2020). Reward-Based Crowdfunding Research and Practice. In Shneor, R., Zhao, L., Flaten, B-T. (Eds). Advances in Crowdfunding. Palgrawe Macmillan, pp. 21-44. 